\title{
HIGH LEVEL OF SEROVAR COPENHAGENI DETECTION IN DOG SERA FROM PATROCÍNIO, MG, BRAZIL
}

\author{
ALTA FREQUENCIA DO SOROVAR COPENHAGENI DETECTADO EM CÃES DO \\ MUNICÍPIO DE PATROCÍNIO, MG, BRASIL
}

\author{
Tayana Larissa LEMOS ${ }^{1}$; Guilherme Nascimento CUNHA ${ }^{2}$; Jacqueline Ribeiro de CASTRO ${ }^{3}$; \\ Mariana Assunção de SOUZA ${ }^{4}$ \\ 1. Graduada em Medicina Veterinária - Centro Universitário de Patos de Minas - Unipam, Patos de Minas, MG. \\ tayanalari@hotmail.com; 2. Professor, Doutor, Centro Universitário de Patos de Minas - Unipam, Patos de Minas, MG.; 3. Professora, \\ Doutora, Centro Universitário de Patos de Minas - Unipam, Patos de Minas, MG; 4. Professora orientadora, Doutora, Centro \\ Universitário de Patos de Minas - Unipam, Patos de Minas, MG
}

\begin{abstract}
This study aimed to evaluate the occurrence of canine leptospirosis and the possible risk factors associated with the disease in the municipality of Patrocínio, MG, Brazil. A cross-sectional observational study was carried out from July through August 2017. The municipality was divided into four regions (north, south, east and west) and a predefined number of neighborhoods (25) were randomly sampled in each region. Samples of blood serum were collected from 241 domiciled male and female dogs of different breeds and ages. To investigate the risk factors for canine leptospirosis, the owners of the animals were asked to fill out an epidemiological questionnaire. The following factors were evaluated: breed, sex, age, presence of rodents, type of diet, access to the street, vaccination, presence of flooded areas, and educational level of the owners. Blood serum samples were evaluated by the Microscopic Agglutination Test (MAT), using a collection of 24 live antigens. Of the 241 dogs evaluated, 32 (13.2\%) were reactive. The most frequent serovars were: Copenhageni (37.5\%) and Canicola (21.8\%), followed by Icterohaemorrhagiae and Grippotyphosa (12.5\%), Pomona, Tarassovi and Butembo (9.3\%) and Hardjo (6.2\%). The presence of canine leptospirosis was associated with purebred dogs $(\mathrm{OR}=0.3059$ [95\% CI: $0.1430-0.6547])$ and vaccination $(\mathrm{OR}=2.581$ [95\% CI: $1.198-5.563]$ ). It was concluded that some dogs in the municipality of Patrocínio, MG have anti-Leptospira spp. antibodies and that the serovars most frequently identified were Copenhageni $(37.5 \%)$ and Canicola $(21.8 \%)$. Pure breeds and vaccination were factors associated with the prevalence of infection.
\end{abstract}

KEYWORDS: Canis lupus familiaris. Leptospira interrogans. MAT. Risk factors

\section{INTRODUCTION}

Leptospirosis is an infectious and zoonotic disease often occurring in developing countries. The disease is caused by the bacterium Leptospira interrogans, a spirochete-like etiological agent that comprises 22 different species, Ten of these species belong to group I (Leptospira interrogans, Leptospira kirschneri, Leptospira noguchii,Leptospira $\quad$ borgpetersenii,Leptospira alexanderi, Leptospira weilii, Leptospira santarosai, Leptospira kmetyi, Leptospira alstoni and Leptospira mayottensis), five to group II (Leptospira licerasiae, Leptospira wolffii, Leptospira fainei, Leptospira broomii and Leptospira inadai) and seven to group III (Leptospira idonii, Leptospira terpstrae, Leptospira vanthielii, Leptospira meyeri, Leptospira biflexa, Leptospira wolbachii). This disease affec chronic renal carrier who eliminates the bacterium through his urine (ADLER; MOCTEZUMA, 2010). Leptospirosis can be transmitted in two ways: through indirect contact with contaminated soil, water and food, or through direct contact with infected animals (ACHA; SZYFRES, 2001). Rats are an important source of infection for dogs, since their habit of sniffing around garbage dumps and construction debris put them in contact with rat urine (NÓBREGA, 2015). On the other hand, dogs are part of the daily life of humans, and are thus an important source of infection for humans, since these animals can be renal carriers of the disease, even if they are asymptomatic (BIRCHARD; SHERDING, 2008). According to Brasil (2016), zoonotic diseases should be prevented through health education, environmental management to control and eliminate reservoirs, and through animal vaccination. The aim of this study was to evaluate the seroprevalence of canine leptospirosis and the risk factors associated with this infection in the 
High level...

municipality of Patrocínio, state of Minas Gerais MG, Brazil.

\section{CONTENTS}

A cross-sectional observational study was carried out during July and August 2017. The research was approved by the Animal Research Ethics Committee of the University Center of Patos de Minas - UNIPAM, under protocol no. 62/17.

The total population of dogs in the municipality of Patrocínio (MG) was estimated based on the human population of 88.648 , according to the Brazilian Institute of Geography and Statistics for the year 2015. The ratio of dogs to humans was calculated based on a proportion of 1:6 (THRUSFIELD, 2004), which resulted in a total of 14,774 animals. The sample was calculated within a confidence interval of $95 \%$ and a variation of $5 \%$. Recent surveys of canine leptospirosis in Brazil have revealed a prevalence ranging from $6.8 \%$ to $35.1 \%$ (FERNANDES et al., 2013; LANGONI et al., 2015); therefore, an average prevalence rate of $20 \%$ was expected, resulting in a total of 241 samples.

The animals of this study were male and female dogs of different breeds and ages, which appeared to be healthy. The blood samples were collected randomly in 25 neighborhoods of the municipality. The number of samples per neighborhood was estimated according to the number of dogs vaccinated per neighborhood during the 2016 Dog Rabies Vaccination Campaign, based on data provided by the municipality's Zoonosis Control Center (ZCC).

Blood samples were collected by venipuncture of the accessory cephalic using $3 \mathrm{~mL}$ syringes and a 25x7 needles. The samples were placed in tubes without anticoagulant and stored under refrigeration $\left(2-8^{\circ} \mathrm{C}\right)$, after which they were centrifuged at $2500 \mathrm{x}$ g to obtain blood serum. The serum samples were subjected the Microscopic Agglutination Test (MAT). A collection of 24 live antigens of Leptospira spp. were used, comprising the serogroup Icterohaemorrhagiae (serovars Copenhageni and Icterohaemorrhagiae, serogroup Hebdomadis (serovar Hebdomadis), serogroup Autumnalis (serovars Autumnalis and Bratislava), serogroup Pyrogenes (serovar Pyrogenes), serogroup Bataviae (serovar Bataviae), serogroup Grippotyphosa (serovar Grippotyphosa), serogroup Canicola (serovar Canicola), serogroup Australis (serovars Australis and Butembo), serogroup Pomona (serovar Pomona), serogroup Sejroe (serovars Hardjo and Wolffi), serogroup Tarassovi

\section{LEMOS et al.}

(serovar Tarassovi), serogroup Javanica (serovar Javanica), serogroup Panama (serovar Panama), serogroup Cynopteri (serovar Cynopteri), serogroup Semaranga (serovar Patoc), serogroup Celledoni (serovar Whitcomb) serogroup Andamana (serovar Andamana), serogroup Ballum (serovar Castellonis), serogroup Shermani (serovar Shermani) and serogroup Djasiman (serovar Sentot). The tests were performed at the Laboratory of Leptospirosis and Brucellosis of UNESP at Jaboticabal, state of São Paulo.

The dogs' owners answered a questionnaire to determine the risk factors associated with canine leptospirosis. The following variables were investigated: breed, sex, age, access to the street, presence of rodents, existence of vacant lots near the home, the animal's diet, occurrence of floods, history of vaccination against leptospirosis, and the owners' level of education.

To calculate the frequency, the ratio of seroreactive dogs to the total number of sampled animals was established based on absolute and relative frequency, using descriptive statistical analysis. The association between the epidemiological variables and positive animals was determined by means of the Odds Ratio nonparametric test for two independent samples, at a significance level of 5\%, using GraphPad version 5.0 for Windows (San Diego, California, USA).

Of the 241 tested dog serum samples, 32 $(13.2 \%)$ were reactive. The most frequent serovar was Copenhageni $(37.5 \%)$ followed by Canicola $(21.8 \%)$ Icterohaemorrhagiae and Grippotyphosa (12.5\%), Pomona, Tarassovi and Butembo (9.3\%), and Hardjo (6.2\%). The serotype with the highest identified titer was Butembo (3200). The titers ranged from 100 to 3200 . Animals reactive to more than one serovar and which presented similar titers were considered positive for all the serovars, counted individually (Table 1). 
Table 1. Seroprevalence and antibody titers to Leptospira spp. serovars in the Microscopic Agglutination Test performed on dogs of the municipality of Patrocínio, MG, Brazil, 2017.

\begin{tabular}{|c|c|c|c|c|c|c|c|}
\hline \multirow[t]{2}{*}{ Serovars } & \multirow[t]{2}{*}{ No. } & \multirow[t]{2}{*}{$\%$} & \multicolumn{4}{|c|}{ Titers } & \multirow[b]{2}{*}{3200} \\
\hline & & & 100 & 200 & 400 & 800 & \\
\hline Copenhageni & 8 & 25 & 4 & 2 & 2 & - & - \\
\hline Canicola & 7 & 21.8 & 7 & - & - & - & - \\
\hline Butembo & 3 & 9.3 & 2 & - & - & - & 1 \\
\hline Tarassovi & 2 & 6.2 & 2 & - & - & - & - \\
\hline Icterohaemorrhagiae & 2 & 6.2 & 2 & - & - & - & - \\
\hline Hardjo & 2 & 6.2 & 1 & 1 & - & - & - \\
\hline Pomona & 2 & 6.2 & 1 & 1 & - & - & - \\
\hline Grippotyphosa & 1 & 3. 2 & 1 & - & - & - & - \\
\hline Icterohaemorrhagiae/ Copenhageni* & 2 & 6.2 & 1 & - & 1 & - & - \\
\hline Grippotyphosa/ Tarassovi* & 1 & 3. 2 & 1 & - & - & - & - \\
\hline Pomona/ Copenhageni/ Grippotyphosa* & 1 & 3.2 & - & 1 & - & - & - \\
\hline Copenhageni/Grippotyphosa* & 1 & 3.2 & 1 & - & - & - & - \\
\hline TOTAL & 32 & 100 & 23 & 5 & 3 & $\mathbf{0}$ & 1 \\
\hline
\end{tabular}

No.: number of reactive animals, * Animals reactive to more than one serovar with the same titration for both.

The prevalence rate found in this study $(13.2 \%)$ was similar to the $13.1 \%$ found by Magalhães et al. (2007) in the city of Belo Horizonte, MG and lower than the $28.3 \%$ reported by Castro et al. (2015) in the city of Uberlândia, MG. Similar frequencies have been reported in other Brazilian states, such as $17.15 \%$ in Pará (PAZ et al., 2015), $19.7 \%$ in Paraíba (AZEVEDO et al. 2011) and $6.8 \%$ in Rio Grande do Norte (FERNANDES et al., 2013).

Most of the animals were reactive to the serovar Copenhageni (37.5\%). Langoni et al. (2015) also reported this serovar as the one with the highest prevalence, while Fernandes et al. (2013) reported this serovar as the third most frequent. According to Mascolli et al. (2002), when the serovar Copenhageni is found to be the most prevalent, this indicates the influence of rodents, especially rats, as disseminators of the disease, since these animals are the main reservoirs of the disease. However, the presence of rodents was not identified as a risk factor for the occurrence of the infection $(\mathrm{P}=0.2966)$ in this study.

The serovar Canicola (21.8\%) was the second most frequent. Castro et al. (2011) reported a similar finding in a study carried out in the city of Uberlândia, MG. Paz et al. (2015), Coiro et al. (2011) and Magalhães et al. (2007) also reported that the serovar Canicola appeared with the highest frequency. This serovar, whose natural hosts are dogs but which is also found in commercially available vaccines, causes the animal to present moderate clinical symptoms, but with a marked condition of leptospiremia, making it an important source of infection for humans (HAGIWARA et al., 2004). In dogs, the renal carrier state is more pronounced in the presence of the serovar Canicola than the serovars found in the serogroup Icterohaemorrhagiae (MAGALHÃES et al., 2006).

About for the risk factors analyzed in the epidemiological questionnaire, the variables of breed $(\mathrm{OR}=0.3059$ [95\% CI: $0.1430-0.6547])$ and vaccination $(\mathrm{OR}=2.581$ [95\% CI: $1.198-5.563])$ were identified as increasing the chance of infection (Table 2). 
Table 2. Distribution of dogs with anti-Leptospira spp. antibodies, according to the risk factors assessed, Patrocínio, MG, Brazil, 2017.

\begin{tabular}{|c|c|c|c|c|c|c|}
\hline \multirow[b]{2}{*}{ Variables } & \multicolumn{3}{|c|}{ Dogs } & \multirow[b]{2}{*}{$O R^{*}$} & \multirow[b]{2}{*}{$95 \% \mathrm{CI}$} & \multirow[b]{2}{*}{$\mathrm{P}$} \\
\hline & Total & Reagents & $\begin{array}{l}\text { Frequency } \\
(\%)\end{array}$ & & & \\
\hline Level of education & 149 & 16 & 10.06 & \multirow{5}{*}{$0.4511 * *$} & \multirow{4}{*}{$0.133-1.527$} & \multirow{4}{*}{0.2494} \\
\hline $\begin{array}{l}\text { Elementary School (compl. } \\
\text { or incomplete) }\end{array}$ & 73 & 12 & 15.06 & & & \\
\hline $\begin{array}{l}\text { Middle School (compl. or } \\
\text { incomplete) }\end{array}$ & 19 & 4 & 21.05 & & & \\
\hline $\begin{array}{l}\text { Higher Education (compl. or } \\
\text { incomplete) } \\
\text { Age }\end{array}$ & & & & & & \\
\hline Puppy $(<1$ year $)$ & 31 & 6 & 16.12 & & \multirow{3}{*}{$\begin{array}{l}0.743 \\
5.844\end{array}$} & \multirow{3}{*}{0.2174} \\
\hline Adult (1-8 years) & 155 & 16 & 9.67 & \multirow[t]{2}{*}{$2.085^{* *}$} & & \\
\hline Elderly ( $>8$ years) & 55 & 10 & 18.18 & & & \\
\hline \multicolumn{7}{|l|}{ Breed } \\
\hline MBD & 164 & 14 & 7.92 & \multirow[t]{2}{*}{0.3059} & \multirow{2}{*}{$0.143-0.65$} & \multirow{2}{*}{0.0037} \\
\hline Purebred & 77 & 18 & 22 & & & \\
\hline \multicolumn{7}{|l|}{ Sex } \\
\hline Male & 112 & 13 & 11.6 & \multirow{2}{*}{1.315} & \multirow{2}{*}{$0.617-2.80$} & \multirow{2}{*}{0.5692} \\
\hline Female & 129 & 19 & 13.17 & & & \\
\hline \multicolumn{7}{|l|}{ Vaccinated } \\
\hline Yes & 102 & 20 & 18.62 & \multirow{2}{*}{2.581} & \multirow{2}{*}{$1.198-5.56$} & \multirow{2}{*}{0.0200} \\
\hline No & 139 & 12 & 7.91 & & & \\
\hline \multicolumn{7}{|l|}{ Vaccinated $<1$ year } \\
\hline Yes & 33 & 6 & 18.18 & \multirow{2}{*}{0.8730} & \multirow{2}{*}{$0.301-2.52$} & 1.0000 \\
\hline No & 69 & 14 & 18.84 & & & 1.0000 \\
\hline Access to the street & & & & & & \\
\hline Yes & 154 & 22 & 13.63 & 1.283 & $0.577-2.85$ & 0.6931 \\
\hline No & 87 & 10 & 10.34 & 1.283 & $0.511-2.85$ & וסנים. \\
\hline Empty lots & & & & & & \\
\hline Yes & 111 & 13 & 9.90 & 0.7750 & $0.363-1.65$ & 0.5706 \\
\hline No & 130 & 19 & 14.61 & 0.1750 & $0.503-1.05$ & $0.5 / 00$ \\
\hline Rodents & & & & & & \\
\hline Yes & 171 & 20 & 10.52 & 0.6402 & $0.294-1.39$ & \\
\hline No & 70 & 12 & 17.14 & 0.0402 & $0.294-1.39$ & 0.2966 \\
\hline Flooding & & & & & & \\
\hline Yes & 42 & 7 & 14.28 & 1.810 & $0.715-4.57$ & 0.2773 \\
\hline No & 199 & 25 & 12.06 & 1.810 & $0.115-4.51$ & 0.2113 \\
\hline Diet & & & & & & \\
\hline Commercial & 158 & 27 & 15 & & & \\
\hline Mixed & 63 & 3 & 4.76 & $1.855^{* *}$ & $0.406-8.47$ & 0.5367 \\
\hline Home cooked & 20 & 2 & 10 & & & \\
\hline
\end{tabular}

*Odds Ratio; **OR calculated for the greatest difference between proportions; MBD: mixed breed dog; $\mathrm{p}<0.05$ indicates a significant difference.

Purebred animals presented a higher chance $(\mathrm{OR}=0.3059 \quad[95 \% \quad \mathrm{CI}: \quad 0.1430-0.6547])$ of infection than mixed breed dogs. This finding contradicts that of Nóbrega (2015) for purebred dogs. A higher frequency of anti-Leptospira spp. antibodies was found among dogs of the Shih Tzu breed. This may be attributed to the fact that small dog breeds are more popular today. Of the 77 purebreds evaluated here, only 17 were large dog breeds. Moreover, another factor possibly contributing to this finding is that these animals are often treated more carefully with respect to prevention measures, triggering vaccine reactions. Of the 18 purebred dogs that presented anti- 
High level...

Leptospira spp. antibodies, 15 had already been vaccinated. Two dogs tested positive for serovars Icterohaemorrhagiae and Copenhageni, which are part of the same serogroup Icterohaemorrhagiae. According to Costa (1996), this classification is based on their antigenic relationship, and their antigenic similarity enables the occurrence of crossreactions. One of the two aforementioned dogs had not been vaccinated against leptospirosis, while the other one was vaccinated 10 months before its blood was sampled.

Vaccination history must be taken into account when interpreting results (OIE, 2014). Vaccines for leptospirosis provide immunity ranging from three to 12 months (RODRIGUES et al., 2013). Of all the animals that showed antiLeptospira spp. antibodies, six had been vaccinated less than 12 months before their blood samples were collected. Among them, four had titers of 100, one had a titer of 200 for serovar Pomona, and one had a titer of 3,200 for serovar Butembo.

Titers of 100 can be interpreted as evidence of previous exposure to Leptospira interrogans or of vaccine reaction (OIE, 2014).

In this study, vaccinated animals had a higher chance of having the infection $(\mathrm{P}=0.0200)$, but when compared to the variable of time elapsed
LEMOS et al.

from last vaccination, the latter showed no influence $(\mathrm{P}=1.0000)$. An absence of association can be explained by the fact that commercially available vaccines normally contain four serovars of the bacterium, i.e., Icterohaemorrhagiae, Canicola, Grippotyphosa and Pomona (TAVARES, 2015). Some vaccines also contain the serovars Copenhageni and Bratislava (FURQUIM, 2016), suggesting that vaccinated animals have not developed immunity or that the test was carried out within the vaccine's duration of protection, indicating that the positive result for anti-Leptospira spp. antibodies was due to vaccination.

The occurrence of leptospirosis was not associated with diet $(\mathrm{P}=0.5367)$, age $(\mathrm{P}=0.2174)$, sex $(\mathrm{P}=0.5692)$, level of education of the owners $(\mathrm{P}=0.2494)$, access to the street $(\mathrm{P}=0.2773)$, presence or absence of vacant lots near the residences $(\mathrm{P}=0.5706)$, and presence of rodents $(\mathrm{P}=0.2966)$.

It is concluded that dogs in the municipality of Patrocínio, MG, have anti-Leptospira spp. antibodies, and that the serovars Copenhageni (37.5\%) and Canicola (21.8\%) occurred most frequently. The risk factors associated with the prevalence of infection were the variables of being purebred and being vaccinated.

RESUMO: O objetivo deste estudo foi avaliar a ocorrência da leptospirose canina e os possíveis fatores de riscos associados à doença no município de Patrocínio - MG. Foi realizado um estudo observacional transversal, durante os meses de Julho à Agosto de 2017. O município foi divido em quatro regiões (norte, sul, leste e oeste) e um número predefinido de bairros (25) foi amostrado aleatoriamente em cada região. Foram colhidas 241 amostras de soro sanguíneo de cães domiciliados de ambos os sexos e de diferentes raças e idades. Para investigação dos fatores de risco da leptospirose canina foi aplicado um questionário epidemiológico aos tutores dos animais, foram avaliados os fatores: raça, sexo, idade, presença de roedores, tipo de dieta, acesso à rua, vacinação, presença de áreas alagadas, terrenos baldios e grau de escolaridade dos tutores. As amostras de soro sanguíneo foram avaliadas pelo exame de Soroaglutinação Microscópica (SAM), com uma coleção de vinte e quatro antígenos vivos. Dos 241 cães avaliados, 32 (13,2\%) apresentaram-se reagentes. Os sorovares de maior frequência foram: Copenhageni $(37,5 \%)$ e Canicola $(21,8 \%)$, seguido por Icterohaemorrhagiae e Grippotyphosa (12,5\%), Pomona, Tarassovi e Butembo (9,3\%) e Hardjo (6,2\%). A presença de leptospirose canina foi associada em cães com raça definida $(\mathrm{OR}=0,3059$ [IC 95\%: 0,1430 - 0,6547]) e vacinação $(\mathrm{OR}=$ 2,581 [IC 95\%: 1.198 - 5.563]). Concluiu-se que existem cães que apresentam anticorpos anti-Leptospira spp., no município de Patrocínio-MG e que os sorovares Copenhageni $(37,5 \%)$ e Canicola $(21,8 \%)$ foram os de maior ocorrência. Apresentar raça definida e a vacinação foram fatores associados à prevalência da infecção.

PALAVRAS-CHAVE: Canis lupus familiaris. Leptospira interrogans. SAM. Fator de risco.

\section{REFERENCES}

ACHA, P. N.; SZYFRES, B. Zoonosis y Enfermedades Transmisibles Comunes al Hombre y a los Animales. $3^{\text {a }}$ Edición. Washington: Organización Panamericana de la Salud, p. 175-186, 2001.

https://doi.org/10.1590/S1135-57272001000300009 
ADLER, B.; MOCTEZUMA, A. P. Leptospira and leptospirosis. Veterinary Microbiology, v. 140, p. 287-296, 2010. https://doi.org/10.1016/j.vetmic.2009.03.012

AZEVEDO, S. S.; FERNANDES, A. R. F.; QUEIROGA, I. M. B. N.; ALVES, C. J.; MORAIS, Z. M.; SANTOS, C. S. A. B.; VASCONCELLOS, S. A. Ocorrência e fatores de risco associados à leptospirose em cães atendidos em hospital veterinário no semiárido paraibano. Braz. J. Vet. Res. Anim. Sci. São Paulo, v. 48, n. 2, p. 161-166, fev. 2011. https://doi.org/10.11606/S1413-95962011000200009

BIRCHARD, S. J.; SHERDING, R. G. Manual Saunders - Clínica de pequenos animais, 2008. Chapter 19, p. 195-199.

BRASIL. Ministério da Saúde. Secretaria de Vigilância em Saúde. Departamento de Vigilância das Doenças Transmissíveis. Manual de vigilância, prevenção e controle de zoonoses: normas técnicas e operacionais. 2016.

CASTRO, J. R.; SOUZA, M. A.; SALABERRY, S. R. S.; NAVES, J. H. F. F.; GUIMARÃES, E. C.; LIMARIBEIRO, A. M. C. Leptospirose canina relacionada à sazonalidade no município de Uberlândia, MG. Ciência Animal, v. 21, n. 2, p. 77-86. 2011.

CASTRO, J. R.; SOUZA, M. A.; NETO, A. B. C.; MOREIRA, R. Q.; SALABERRY, S. R. S.; GUIMARÃES, E. C.; LIMA, A. M. C. Presence of Antibodies Against Leptospira spp. in Dogs of Uberlandia, MG, Brazil. Biosci. J.,Uberlândia, v. 31, n. 4, p. 1183-1188, July/Aug. 2015. https://doi.org/10.14393/BJ-v31n4a201526173

COIRO, C. J.; LANGONI, H. SILVA, R. C.; ULLMANN, L. S. Fatores de Risco para Leptospirose, Leishmaniose, Neosporose e Toxoplasmose em Cães Domiciliados e Peridomíciliados em Botucatu-SP. Vet.Zootec. v. 18, n. 3, p. 393-407, set. 2011.

COSTA, M. C. R. Avaliação da imunidade cruzada entre leptospiras Hardjo e Wolffi. Dissertação (Mestrado em Medicina Veterinária Preventiva) - Escola de Veterinária, UFMG, Belo Horizonte, 1996.

FERNANDES, A. R.; FERNANDES, A. G.; ARAÚJO, V. J. A.; HIGINO, S. S. S.; SILVA, M. L. C. R.; ALVES, C. J.; AZEVEDO, S. S. Soroepidemiologia da leptospirose canina na região metropolitana de Natal, estado do Rio Grande do Norte. Braz. J. Vet. Res. Anim. Sci., v. 50, n. 3, p. 226-232, 2013. https://doi.org/10.11606/issn.1678-4456.v50i3p226-232

FURQUIM, M. E. C. Análise retrospectiva de exames sorológicos de leptospirose animal executados no Laboratório de Leptospirose e Brucelose da UNESP, Câmpus Jaboticabal, de 2007 a 2015. Dissertação (Mestrado em Medicina Veterinária Preventiva) - Faculdade de Ciências Agrárias e Veterinárias, UNESP, São Paulo, 2016.

HAGIWARA, M. K.; LUSTOSA, M.; KOGIKA, M. M. Leptospirose Canina. Vet News, n. 67, 2004.

LANGONI, H.; PONTE, M. C.; BARBOSA, D.; MANZI, M. P.; SILVA, R. C.; MENOZZI, B. D. Pesquisa de anticorpos e DNA de Leptospira spp. em soro canino. Vet. e Zootec., v. 22, n.3, p. 429-436, set. 2015.

MAGALHÃES, D. F.; SILVA, J. A.; MOREIRA, E. C.; WILKE, V. M. L.; HADDAD, J. P. A.; MENESES, J. N. C. Prevalência de aglutininas anti-Leptospira interrogans em cães de Belo Horizonte, 2001 a 2002. Arq. Bras. Med. Vet. Zootec., v.58, n.2, p.167-174, nov. 2006. https://doi.org/10.1590/S0102-09352006000200004

MAGALHÃES, D. F.; SILVA, J. A.; MOREIRA, E. C.; WILKE, V. M. L.; NUNES, A. B. V.; HADDAD, J. P. A.; MENESES, J. N. C. Perfil dos cães sororreagentes para aglutininas anti-Leptospira interrogans em Belo Horizonte, Minas Gerais, 2001/2002. Arq. Bras. Med. Vet. Zootec.,v.59, n.5, p.1326-1329. 2007. https://doi.org/10.1590/S0102-09352007000500035 
MASCOLLI, R.; PINHEIRO, S. R.; VASCONCELLOS, S. A.; MORAIS, Z. M.; FERREIRA, F.; PINTO, C. O.; SUCUPIRA, R. A.; DIAS, R. A.; MIRAGLIA, F. CORTEZ, A.; SILVEIRA DA COSTA, S.; TABATA, R.; MARCONDES, A. G. Inquérito sorológico para leptospirose em cães do município de Santana de Parnaíba, São Paulo, utilizando a campanha de vacinação anti-rábica do ano de 1999. Arq. Inst. Biol., São Paulo, v.69, n.2, p.25-32, Apr/Jun 2002.

NÓBREGA, K. Q. Estudo das principais doenças infecciosas em cães atendidos no hospital veterinário da Universidade de Brasília entre 2011 e 2014. 2015. Dissertação (Graduação em Medicina Veterinária) Faculdade de Agronomia e Medicina Veterinária da Universidade de Brasília, Brasília, 2015.

OIE - World Organization for Animal Health. Manual of diagnostic test and vaccines for terrestrial animals. 2014. Available at: $<$ http://wahis2-

devt.oie.int/fileadmin/Home/fr/Health_standards/tahm/2.01.09_LEPTO.pdf $>$. Accessed on 16 Sep 2017.

PAZ, G. S.; ROCHA, K. S.; LIMA, M. S.; JORGE, E. M.; PANTOJA, J. C. F.; MORAES, C. C. G.;

LANGONI, H. Seroprevalence for brucellosis and leptospirosis in dogs from Belém and Castanhal, State of Pará, Brazil. Acta Amazonica, v. 45, n. 3, p. 265 - 270. 2015. https://doi.org/10.1590/1809-4392201403486

RODRIGUES, A. M. A.; VASCONCELOS, S. A.; GONÇALES, A. P.; MORAES, Z. M.; SOUZA, G. O.; HAGIWARA, M. K. Anticorpos revelados pelo teste de inibição do crescimento de leptospirasin vitro (TICL) contra os sorovares Canicola, Icterohaemorrhagiae e Copenhageni em cães adultos revacinados anualmente com vacina comercial contendo bacterinas dos sorovares Canicola, Icterohaemorrhagiae, Grippotyphosa e Pomona.Pesq. Vet. Bras., n. 33, v. 5, p. 627-634, maio. 2013. https://doi.org/10.1590/S0100736X2013000500013

TAVARES, D. C. Transtornos reprodutivos causados por agentes infecciosos em animais de canis comerciais da microrregião de Ribeirão Preto, Estado de São Paulo. 2015. Tese (Doutorado em Medicina Veterinária, área de Reprodução Animal) - UNESP, São Paulo, 2015.

THRUSFIELD, M. Epidemiologia Veterinária. 2. ed. São Paulo: Roca, 2004. 572 p. 